\title{
KEARIFAN LOKAL DALAM PENATAAN RUANG KAWASAN BENCANA VULKANIK STUDI KASUS: DESA KEPUHARJO CANGKRINGAN
}

\author{
Catharina Dwi Astuti Depari ${ }^{1}$
}

Diterima: 20 Januari 2015 Disetujui: 13 Februari 2015

\begin{abstract}
Sejumlah kasus manajemen bencana di Asia Tenggara membuktikan bahwa kearifan lokal berperan besar dalam meningkatkan ketahanan masyarakat terhadap dampak bencana. Pendekatan mitigasi bencana yang mengintegrasikan antara kearifan lokal dengan pengetahuan modern saat ini semakin aktif dilakukan sehingga partisipasi lokal merupakan syarat mutlak agar pendekatan ini dapat dilakukan.Secara arsitektural, sistem tata ruang merefleksikan nilai-nilai budaya lokal, termasuk di dalamnya pengetahuan masa lampau akan dampak bencana. Masyarakat Desa Kepuharjo, salah satu komunitas Merapi yang bermukim di zona rawan bencana, dikenal memiliki kearifan lokal yang berhubungan erat dengan pengetahuan mitigasi bencana dan kemudian diekspresikan melalui tradisi budaya, ritual keagamaan dan sistem tata ruangnya. Penelitian bertujuan untuk menegaskan peran kearifan lokal sebagai elemen penting dalam upaya meningkatkan ketahanan masyarakat Kepuharjo terhadap dampak erupsi dan mengungkap penerapan nilai-nilai tersebut ke dalam tata ruang setempat. Penelitian menggunakan metode interpretasi-etnografis yang mendasarkan interpretasi menurut pengetahuan lokal dan wawasan teoritis peneliti akan mitigasi bencana dan tata ruang.
\end{abstract}

Keywords: kearifan lokal, mitigasi bencana, tata ruang, interpretasi-etnografis.

\begin{abstract}
Some successful disaster management especially in East Asia have demonstrated how the local wisdom could contribute to increasing the resilience of its communities toward disaster impacts. A new approach integrating local wisdom with modern science is now continuously developed and, for this reason, a bottom up approach in which community's aspirations accommodated must be well-considered. In design context, spatial ordering system could symbolize local values in which inherited knowledge towards disaster mitigation is embed. In terms of Merapi's disaster prone-areas, the communities of Kepuharjo Village have inherited knowledge to coping with volcanic impacts that mostly expressed through their traditions and rites. The research aims to emphasize local wisdom as an essential element that contributes to increasing the community's resilience towards volcanic impacts. By investigating the types of local wisdom still existed and understood by the local citizens, and revealing the implementation of those values into the local's urban structure. The research employs interpretive, and ethnography approaches in which interpretations based on local community's experience and researcher's knowledge towards the research focus established.
\end{abstract}

Keywords: local wisdom, spatial ordering system, inherited knowledge, disaster mitigation, volcanic impacts.

\section{Pendahuluan}

Posisi geografis Indonesia yang terletak pada pertemuan antara 3 (tiga) lempeng benua, yaitu Lempeng Eurasia, Australia, dan Pasifik, mengakibatkan terbentuknya sejumlah gunungapi di wilayah kepulauan Indonesia. Menurut Pusat Vulkanologi dan Mitigasi Bencana Geologi

\footnotetext{
${ }^{1}$ Program Studi Arsitektur Fakultas Teknik, Universitas Atma Jaya Yogyakarta
} 
(2010), Indonesia memiliki 129 gunungapi berstatus aktif yang terhubung dengan gugusan gunungapi aktif lainnya di dunia (ring of fire) sehingga mengakibatkan Indonesia sangat potensial mengalami bencana vulkanik dengan risiko bencana yang mematikan. Sejarah kebencanaan geologis di Indonesia mencatat besarnya dampak kerugian material maupun in-material yang diakibatkan oleh peristiwa erupsi khususnya oleh aktivitas gunung Merapi. Gunung Merapi telah mengalami 1.000 kali peristiwa erupsi sejak tahun 1.000 serta menelan korban jiwa hingga mencapai 175.000 orang. Selain erupsi tahun 1872 dan 1931, peristiwa erupsi Merapi terbesar adalah yang terjadi pada periode Oktober-November 2010 dengan korban jiwa mencapai 386 orang (Wahyunto \& Wasito).

Secara antropologis, karakteristik gunung berperan besar dalam menentukan bentuk dan ciri budaya masyarakat pemukim. Bagi masyarakat Merapi, erupsi adalah gejala alam siklis yang sangat wajar terjadi sehingga warga dituntut untuk mampu beradaptasi dengan lingkungan sekitar. Salah satu ekpresi warga dalam beradaptasi dengan gunung adalah melalui kegiatan ritual budaya dengan mempersembahkan sesajen bagi para penguasa gunung. Ritual ditujukan untuk mengungkapkan rasa syukur atas anugerah yang diberikan sekaligus upaya untuk menjaga relasi yang harmonis dengan gunung. Dengan demikian, dapat disimpulkan adanya proses personifikasi terhadap Merapi yang dipercaya memiliki kekuatan magis dalam menentukan keberlangsungan hidup masyarakat setempat. Personifikasi tersebut sekaligus memperlihatkan adanya hubungan emosional yang sangat erat antara warga pemukim dengan gunung Merapi. Meskipun risiko bencana yang ditimbulkan oleh aktivitas vulkanik tergolong tinggi, namun melimpahnya keuntungan alamiah gunung menarik para pendatang untuk bermukim di sekitar wilayah gunung. Secara inkremental, warga membangun di sekitar wilayah gunung bahkan menjangkau areal zona berbahaya sehingga kawasan gunung semakin rentan terhadap potensi bencana. Kerentanan kawasan semakin diperparah dengan berkembangnya aktivitas lokal bersifat eksploratif termasuk praktik ilegal yang mengubah fungsi hutan menjadi areal pertanian dan ladang. Kerentanan kawasan terhadap resiko bencana dapat direduksi apabila dilakukan pembatasan terhadap aktivitas-aktivitas yang berpotensi mengganggu keseimbangan ekologis gunung. Selain itu, perlu dikembangkan inovasi baru dalam manajemen bencana yang berlandaskan pada pengetahuan modern dan lokal (indigenus knowledge). Berdasarkan hasil observasi di lapangan, kebijakan tata ruang kawasan rawan bencana vuknik cenderung mengadopsi nilai-nilai masa kini dengan pendekatan mekanis dan represif, sedangkan potensi kearifan lokal setempat cenderung diabaikan.

Pengetahuan mengenai mitigasi bencana dan model-model adaptasi terhadap bencana sebenarnya telah diwariskan secara turun menurun oleh para nenek moyang yang telah terlebih dahulu mempelajari karakteristik gunung. Umumnya pengetahuan masa lampau tersebut diteruskan dari mulut ke mulut dan dituangkan ke dalam hukum adat, kaidah, norma, aturan tradisional dan kearifan lokal (Ernawi, 2010). Namun karena bentuknya yang verbal, hampir seluruh data historis mengenai pengetahuan tersebut nyaris punah. Menurut Geertz (2007) bahwa kearifan lokal merupakan norma yang berlaku dalam suatu masyarakat dan menjadi acuan yang mengatur perilaku sehari-hari masyarakat setempat sehingga dapat pula menjadi faktor yang menentukan status sosial seseorang dalam konteks hidup bermasyarakat (Geertz dalam Ernawi, 2010). Kearifan lokal juga dimaknai sebagai prinsip-prinsip dan cara-cara tertentu yang dianut, dipahami, dan diaplikasikan oleh masyarakat lokal dalam berinteraksi dan berinterelasi dengan lingkungannya dan kemudian ditransformasikan ke dalam sistem nilai dan norma adat setempat (Zulkarnain dan Febriamansyah dalam Permana \& Nasution, 2011). Berdasarkan pemahaman tersebut, maka penelusuran kearifan lokal Merapi dalam kaitannya dengan ketahanan kawasan menghadapi ancaman bencana erupsi serta pengaruhnya pada proses tata ruang kawasan permukiman setempat bukanlah hal yang tidak mungkin dilakukan.

Masuknya ideologi modern dan pengaruh globalisasi tentunya akan berimbas pada bergesernya nilai-nilai lokal termasuk ancaman terhadap keberlangsungan kearifan lokal suatu tempat. Menanggapi gejala ini, penelitian ditujukan untuk menegaskan kembali hakikat kearifan lokal sebagai elemen penting untuk meningkatkan ketahanan wilayah dalam menghadapi ancaman erupsi. Sasaran penelitian yang ingin dicapai adalah mengungkap konsep, kaidah atau prinsip membangun masa lampau dalam konteks kebencanaan dan tingkat keberlanjutan kearifan 
lokal tersebut dalam persepsi warga Merapi saat ini dan menilai bagaimana kearifan lokal tersebut diadopsi pada struktur ruang permukiman setempat. Metode penelitian mengadopsi pendekatan interpretatif-etnography dengan memilih kawasan Desa Kepuharjo sebagai objek studi dan menjaring informasi dari warga melalui questionnaire. Penelitian menemukan adanya kelemahan sebagian warga dalam memahami secara detail pengetahuan masa lampau mengenai mitigasi bencana yang terkandung dalam kearifan lokal setempat serta masih besarnya ketergantungan warga pemukim terhadap daerah huniannya yang kini ditetapkan sebagai zona berbahaya.

\section{Metodologi}

Paradigma penelitian fenomenologi diterapkan untuk mengkaji ruang permukiman kawasan Desa Kepuharjo sebagai sebuah material culture melalui dua pendekatan, yaitu interpretive dan ethnography. Sedangkan kajian literatur difungsikan sebagai background knowledge yang digunakan oleh peneliti untuk menjaga objektivitas saat membangun interpretasi terhadap sistem kebudayaan, sistem sosial dan sistem setting objek studi. Pendekatan penelitian interpretive dan etnografi diterapkan sebagai metode analisis menurut sudut pandang budaya sehingga proses penelitian akan didahului dengan tahap inventarisasi dan interpretasi terhadap konsep-konsep mitigasi bencana masa lampau melalui kearifan lokal yang selama ini diwariskan secara turun temurun.

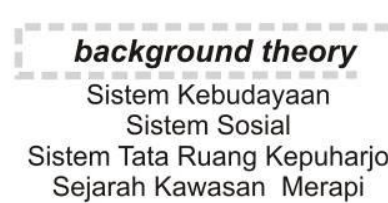

Sejarah Kawasan Merapi parameter

Kearifan Lokal, Tata Ruang, Bencana Vulkanik

variabel Struktur Ruang pola fungsi lahan dan bangunan, sistem jalan Vulkanik Karakter gunung vulkanik, sejarah erupsi, pengalaman lokal berkaitan dengan erupsi, mitigasi bencana Kearifan Lokal sastra berupa cerita rakyat atau foklore, mitos, aturan membangun tradisional Aktivitas Agama, Sosial, Budaya dan Ekonomi ritual keagamaan, tradisi budaya, upacara-upacara adat, aktivitas ekonomi, aktivitas sosial

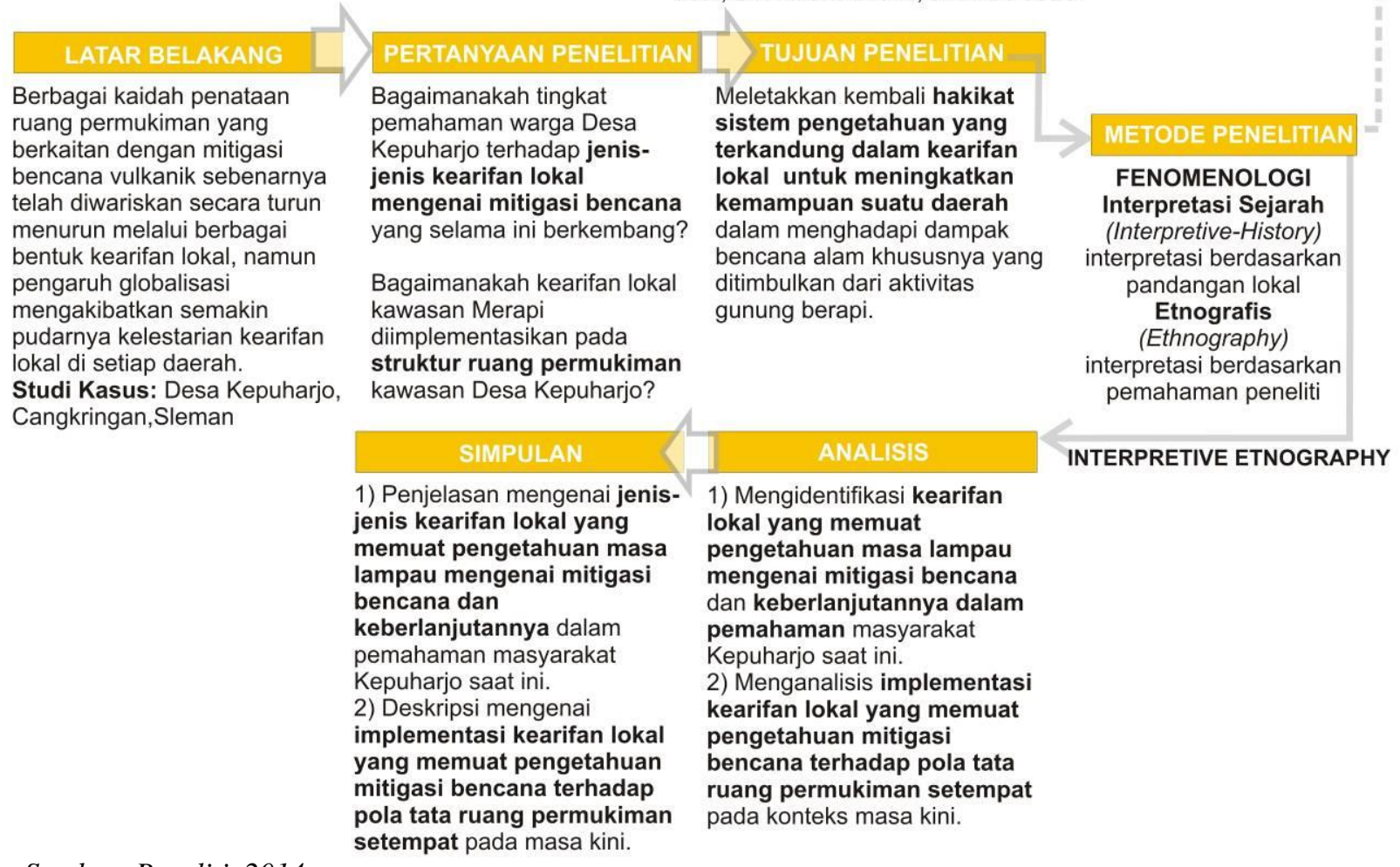

Sumber: Peneliti, 2014 
Tujuan dari pendekatan etnografi ditujukan untuk menghasilkan teori lokal yang hanya dapat diterapkan di suatu lokasi tertentu dan sangat bergantung pada metode participant observation, yaitu pada partisipasi aktif peneliti secara total khususnya pada tahap interpretasi. Hal ini berbeda dengan pendekatan interpretive yang mendasarkan interpretasi terhadap objek studi menurut pandangan dan pengalaman masyarakat lokal (Groat \& Wang, 2002).

\section{Analisis}

Kebudayaan dapat dibagi menjadi 3 kategori, yaitu: 1) sistem kebudayaan yang bersifat abstrak berupa nilai-nilai keyakinan atau pandangan hidup; 2) sistem sosial berupa pola kegiatan yang lebih konkrit daripada sistem kebudayaan; dan 3) kebudayaan fisik seperti peralatan, perabot dan bangunan (Sardjono, et al., 2013). Dengan demikian, kearifan lokal sebagai sistem kebudayaan dapat diekspresikan melalui sistem sosial yang lebih konkrit, yaitu berupa kegiatan upacara, kesenian, agama termasuk karya sastra yang antara lain berupa folklore dan mitos. Sebagai sebuah sistem wadah, pembentukan dan perubahan pada ruang arsitektur sangat dipengaruhi oleh perjalanan budaya, tranfsornasi pada nilai-nilai keyakinan dan pandangan hidup, sistem nilai, adat istiadat dan aktivitas yang berlangsung di dalamnya sehingga mengakibatkan ruang arsitektur memiliki suatu makna filosofis tertentu (Rapoport, 1977), yang kemudian oleh Schultz (1980) disebut sebagai genius loci atau jiwa tempat. Ditegaskan oleh Schultz (1980) bahwa arsitektur merupakan media visualisasi dari jiwa tempat dan penataan seluruh elemennya dapat didasari oleh adanya faktor-faktor spiritual atau keyakinan. Manusia menyadari alam sebagai sebuah struktur yang terdiri dari elemen-elemen natural yang saling bertautan berupa bumi dan langit, dan sebaliknya makna simbolik yang terkandung di dalamnya dapat diungkap melalui kajian terhadap hubungan antara kedua elemen tersebut (Schultz, 1980). Kekuatan magis sebagai esensi ruang merupakan faktor penting yang mempengaruhi tindakan manusia ketika membangun dunia mikrokosmosnya yang ddiekspresikan melalui organisasi ruang dengan berpedoman pada suatu artikulasi tertentu. Sehubungan dengan penelitian, tata ruang permukiman Merapi di masa lampau jika ditelusuri lebih lanjut dapat menjadi media untuk mengungkap kearifan lokal yang mendasari penataannya dan lebih detail yang berkaitan dengan pengetahuan mitigasi bencana di masa lampau. Sebagai sebuah artifak budaya dan simbol kearifan lokal, arsitektur memiliki tiga aspek utama yang saling mempengaruhi, yaitu: 1) Contend sebagai kandungan makna menurut masyarakat setempat dengan segala aktivitas dan kebudayaannya; 2) Container, yang menyangkut wadah, bentuk fisik, lingkungan binaan atau bangunan yang mewadahi kegiatan, dan 3) Context, yang menyangkut lingkungan di sekitar wadah (Rapoport dalam Haryadi \& Setiawan, 2010).

\begin{tabular}{|c|c|c|c|c|c|}
\hline NILAI BUDAYA & $\begin{array}{l}\text { PANDANGAN } \\
\text { HIDUP }\end{array}$ & $\begin{array}{c}\text { NILAI } \\
\text { YANG DIANUT }\end{array}$ & $\begin{array}{l}\text { CARA } \\
\text { HIDUP }\end{array}$ & $\begin{array}{l}\text { SISTEM } \\
\text { AKTIVITAS }\end{array}$ & $\begin{array}{l}\text { SISTEM } \\
\text { SETTING }\end{array}$ \\
\hline $\begin{array}{l}\text { latar belakang, } \\
\text { pandangan } \\
\text { hidup, } \\
\text { nilai-nilai } \\
\text { keyakinan, } \\
\text { kebiasaan hidup }\end{array}$ & $\begin{array}{l}\text { keinginan, } \\
\text { pilihan hidup } \\
\text { idealisme }\end{array}$ & $\begin{array}{l}\text { prioritas dari } \\
\text { berbagai unsur } \\
\text { yang dianggap } \\
\text { penting }\end{array}$ & $\begin{array}{l}\text { pilihan peran, } \\
\text { perilaku, } \\
\text { alokasi sumber } \\
\text { kehidupan }\end{array}$ & $\begin{array}{l}\text { organisasi } \\
\text { kegiatan }\end{array}$ & $\begin{array}{l}\text { organisasi wadah } \\
\text { kegiatan (tata } \\
\text { ruang) }\end{array}$ \\
\hline
\end{tabular}

Sumber: Haryadi dan Setiawan, 2010 diskema ulang oleh penulis, 2014

\section{Skema 2. Hubungan Antara Budaya, Sistem Aktivitas dengan Setting Ruang}

Dalam konteks keyakinan Jawa Hindu yang hingga saat ini masih mempengaruhi sebagian perilaku dan adat istiadat masyarakat Merapi, manusia tidak pertama-tama melihat wilayah huninya dalam batas-batas fisik belaka namun turut menjangkau dimensi kosmologis yang pemahaman mengenainya melampaui batas alam pikir manusia pada umumnya 
(Wiryomartono, 1995:30). Konsep manunggaling kawula lan Gusti dimanifestasikan oleh masyarakat Jawa ke dalam bentuk persenyawaan antara arsitektur, alam, manusia dan Tuhan sehingga tata wilayah dan tata bangunan lebih diutamakan demi kelangsungan hidup secara kosmis, dibanding dengan alasan duniawi dan estetika (Setyowati, 2007: hal.199).

\section{Kondisi Eksisting Kawasan Desa Kepuharjo}

Desa Kepuharjo terletak pada wilayah sekitar 7 kilometer ke arah Utara dari ibukota Kecamatan Cangkringan dan 27 kilometer ke arah timur laut dari ibukota Kabupaten Sleman. Desa Kepuharjo dilalui oleh Sungai Gendol yang terdapat di bagian Timur dan menjadi jalur pembatas dengan wilayah Desa Glagaharjo. Sungai Gendol berperan sebagai jalur limpahan pasir dan batu yang terbawa oleh lahar dingin yang diakibatkan oleh erupsi. Berdasarkan pengalaman erupsi November 2010, Sungai Gendol diidentifikasi sebagai jalur sungai yang membawa dampak bencana yang paling mematikan sehingga memusnahkan hampir seluruh permukiman yang berada di sekitar jalur sungai. Menanggapi potensi bahaya tersebut, maka setiap menjelang musim penghujan, seluruh perangkat pemerintahan setempat menjalin kerja sama dengan sejumlah instansi dan relawan untuk memberikan peringatan dini kepada warga lokal khususnya pada para penambang pasir yang masih beroperasi di sekitar sungai Gendol. Berdasarkan data kependudukan setempat, sebagian besar masyarakat Kepuharjo mengandalkan hidupnya dari sektor pertambangan pasir dengan tipe galian C selain bekerja di sektor pertanian maupun peternakan dan hanya sebagian kecil dari warga yang berprofesi sebagai wiraswasta maupun PNS (Desa Kepuharjo, 2013).

Pemerintah Kabupaten Sleman menetapkan Desa Kepuharjo sebagai Zona Kawasan Pengembangan Bagian Utara yang berkarakteristik khusus dengan rencana pengembangan sebagai kawasan hutan lindung, pertanian lahan kering, pertambangan pasir terbatas, permukiman pedesaan dan kawasan dengan kepadatan rendah di kawasan yang ditetapkan sebagai kawasan lindung dan kepadatan sedang untuk kawasan sub pusat pengembangan (Sleman, 2013). Berdasarkan pengamatan di lapangan, fungsi lahan yang mendominasi wilayah Kepuharjo adalah berupa hutan semak belukar sedangkan area permukiman berkepadatan rendah hingga sedang dibangun ke arah jalan utama dan berorietasi ke Selatan. Meskipun demikian, ditemukan sejumlah hunian di zona berbahaya yang berpotensi mengancam keselamatan penghuni. Kondisi tersebut memperlihatkan bahwa rencana Pemerintah belum seutuhnya dapat diimplementasikan di wilayah desa.

Dalam konteks kebencanaan, kawasan Desa Kepuharjo termasuk ke dalam kategori Kawasan Rawan Bencana II dan III (Kabupaten Sleman, 2013) sehingga perlu diantisipasi sejumlah dampak bencana vulkanik yang berupa awan panas, aliran lava, lontaran batu (pijar), guguran lava, hujan abu lebat, hujan lumpur panas, aliran lahar, dan gas beracun. Sebagai kawasan rawan bencana II dan III, Desa Kepuharjo termasuk ke dalam zona daerah yang paling beresiko terhadap dampak erupsi. Sedankan dalam aspek budaya, Desa Kepuharjo memiliki beberapa jenis kesenian daerah yang merupakan kesenian asli setempat seperti jathilan. Selain itu, diperoleh informasi bahwa masyarakat masih mempertahankan adat dengan menjalankan berbagai upacara tradisional yang bertemakan tentang daur hidup (Desa Kepuharjo, 2013), yaitu :

1) Upacara Mitoni, yaitu selamatan pada saat usia kehamilan mencapai tujuh bulan.

2) Upacara Puputan, yaitu upacara selamatan pada saat tali pusar bayi sudah lepas.

3) Jagongan, yaitu acara tidak tidur semalam suntuk atau bertandang di rumah keluarga yang baru melahirkan bayi pada malam hari selama satu minggu.

4) Upacara dandan kali atau becekan, yaitu upacara kenduri di dasar Sungai Gendol dengan menyembelih kambing jantan oleh masing-masing dusun dan disembelih secara serentak yang dilaksanakan pada hari Jumat Kliwon atau bulan Oktober tahun masehi.

5) Selapanan, yaitu acara kenduri atau Slamatan yang dilakukan bertepatan dengan usia bayi tiga puluh lima hari sebagai ungkapan rasa syukur .

6) Upacara kematian.

7) Upacara khitanan, yaitu tanda bahwa anak lelaki sudah mulai menginjak aqil balig. 
8) Upacara pernikahan, dengan berbagai urutan pernak pernik tradisi Jawa.

Keyakinan mitologis dan religi umumnya diekspresikan melalui upacara budaya dan ritual keagamaan yang dilakukan secara berkala. Menurut hasil wawancara terhadap 30 warga Kepuharjo, ditemukan bahwa tidak semua warga memiliki pemahaman yang utuh terhadap kearifan lokal setempat yang disebabkan oleh adanya perubahan pada kondisi demografis setempat. Paska peristiwa erupsi tahun 2010, penghuni yang saat ini bermukim di zona berbahaya didominasi oleh para pendatang yang berasal dari luar wilayah desa dan merupakan kerabat dari penghuni sebelumnya.

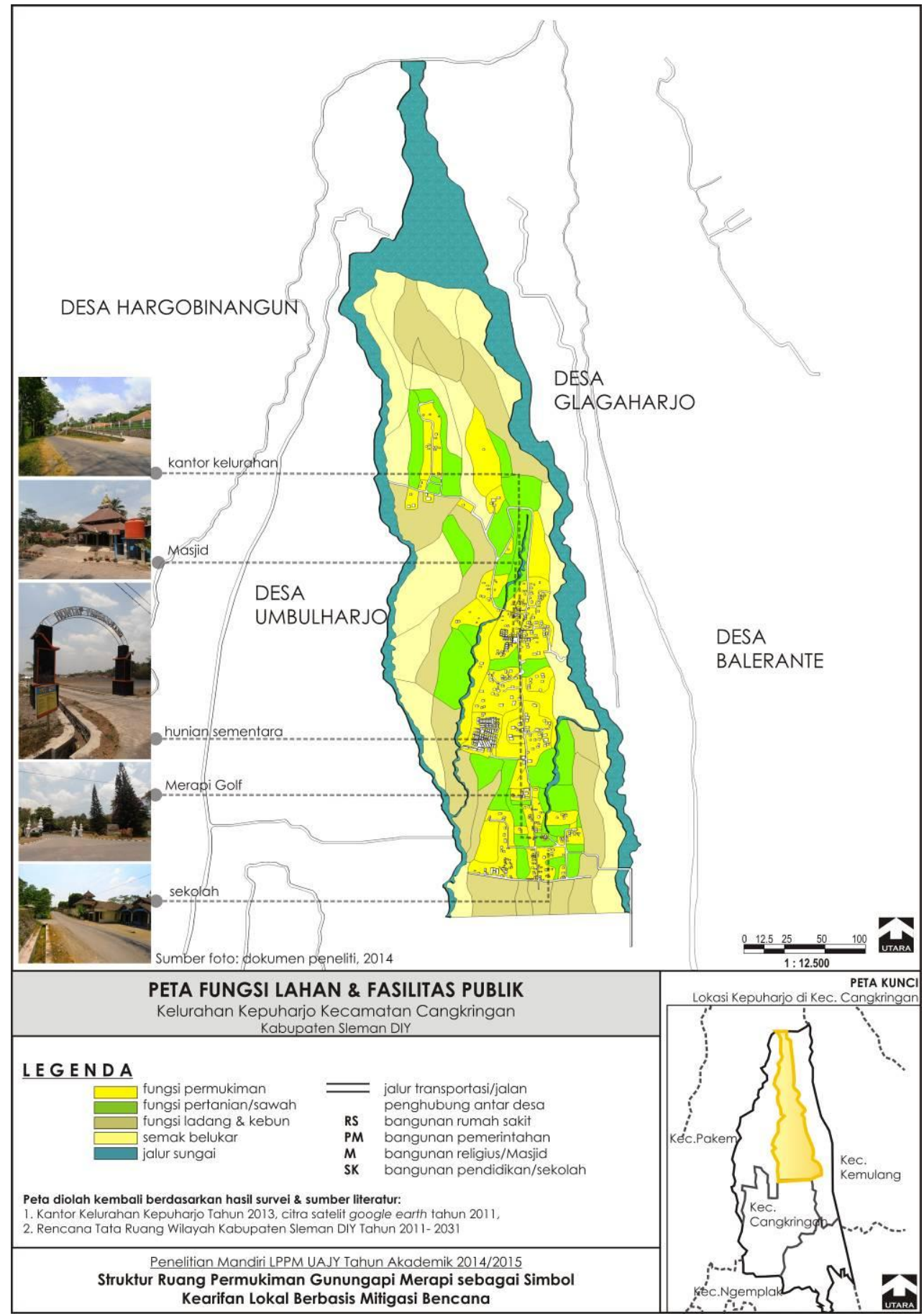

Sumber: Peneliti, 2014

Gambar 1. Sebaran fungsi lahan dan fasilitas umum Desa Kepuharjo Cangkringan 
Sebagian besar dari penghuni tersebut telah bermukim di zona berbahaya selama antara 510 tahun, hingga dapat dipahami jika penguasaan responden terhadap kearifan lokal Merapi tidak cukup baik. Sedangkan penghuni awal pada zona berbahaya telah direlokasi ke hunian sementara yang dibangun oleh Pemerintah Daerah bekerja sama dengan Kementerian Pekerjaan Umum pada zona yang relatif lebih aman. Namun pada kenyataannya, warga masih tetap enggan untuk sepenuhnya menempati fasilitas hunian sementara, dan pada saat tertentu cenderung menempati hunian awalnya yang kembali terbangun di zona berbahaya. Pola perilaku demikian sangat membahayakan keselamatan jiwa warga. Selain itu, apabila pengetahuan mengenai mitigasi bencana, baik yang bersumber dari kearifan lokal maupun pengetahuan modern tidak disalurkan kepada para pandatang yang kini tinggal di zona rawan bencana, maka tingkat kerentanan masyarakat Kepuharjo terhadap dampak bencana tetap tinggi.

\section{Tingkat Pemahaman Responden terhadap Kearifan Lokal Berbasis Mitigasi Bencana}

Responden yang dipilih adalah warga yang bermukim di zona yang paling dekat dengan pusat bencana. Pemilihan responden dilakukan secara random dengan tujuan untuk mengidentifikasi tingkat penguasaan warga terhadap pengetahuan atau kearifan lokal yang memuat pengetahuan mitigas bencana tanpa memandang kategori usia, jenis kelamin, agama yang dianut dan faktor lainnya yang melekat pada pribadi warga. Jumlah responden yang ditetapkan adalah 30 warga dan bermukim pada radius 5 kilometer dari puncak Merapi Rata-rata responden yang menjadi narasumber informasi bagi penelitian adalah warga desa Kepuharjo yang tidak memiliki posisi penting dalam struktur sosial kemasyarakatan setempat dan umumnya berada pada range usia antara 41 tahun sampai 50 tahun, beragama Islam dan hidup bersama dengan 3 (tiga) sampai 5 (lima) anggota keluarga lainnya. Sebagian besar responden warga Merapi berprofesi sebagai petani dan pedagang serta sisanya berprofesi sebagai penambang pasir, penggarap ladang dan pegawai pemerintah maupun swasta. Rata-rata responden menghuni tempat tinggalnya belum lebih dari 10 (sepuluh) tahun dan hanya sebagian kecil yang tetap menghuni lebih dari 50 tahun. Pembangunan kembali permukiman pada zona berbahaya masih tetap dilakukan oleh warga paska erupsi tahun 2010, meskipun telah diberlakukan sejumlah larangan oleh Pemerintah Daerah.

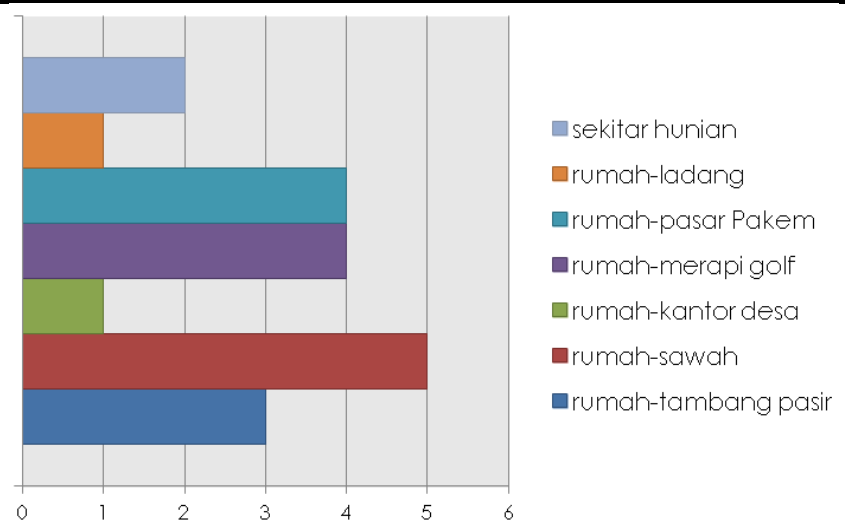

Sumber: Peneliti, 2014

\section{Grafik 1. Rute Sehari-Hari Responden Di Sekitar Wilayah Merapi}

Dalam konteks kehidupan sehari-hari, perlu diketahui bagaimana perilaku sosial dan ekonomi warga Kepuharjo. Mengingat profesi responden sebagian besar adalah penggarap sawah, maka rute sehari-hari yang dilalui adalah dari rumah ke areal sawah dengan jarak tempuh rata-rata 1 kilometer dari hunian. Selain rute tersebut, sebagian responden lainnya yang berprofesi sebagai pedagang umumnya menempuh perjalanan yang lebih jauh dari rumah ke pasar tradisional Pakem dengan jarak tempuh sekitar 7 (tujuh) kilometer, sedangkan warga yang 
berprofesi sebagai karyawan pusat bisnis Merapi golf menempuh jarak sekitar 1 (satu) hingga 3 (tiga) kilometer dari hunian. Khusus responden yang berprofesi sebagai penambang pasir, jarak tempuh menuju ke sungai Gendol yang merupakan sumber tambang pasir adalah antara 100 meter hingga 5 (lima) kilometer. Umumnya, warga menggunakan sepeda motor dan sepeda konvesional sebagai sarana transportasi sehingga ancaman terhadap keselamatan penghuni cenderung cukup besar

Kegiatan sosial budaya yang kuat diingat oleh responden dan tetap berlangsung hingga saat ini adalah Labuhan Gunung Merapi, yaitu tradisi yang ditujukan untuk memohon keselamatan dari penunggu Merapi serta sebagai ungkapan rasa syukur atas berkat yang diberikan oleh gunungapi Merapi. Selain Labuhan, terdapat beberapa tradisi yang cukup kuat diingat oleh para responden seperti tradisi kenduri, becekan, dandan kali dan tradisi sedekah Kali Gendol yang ecara spesifik ditujukan untuk memohon kepada penunggu gunungapi Merapi agar air sungai memiliki jumlah yang cukup dan aman untuk dikonsumsi oleh warga setempat.

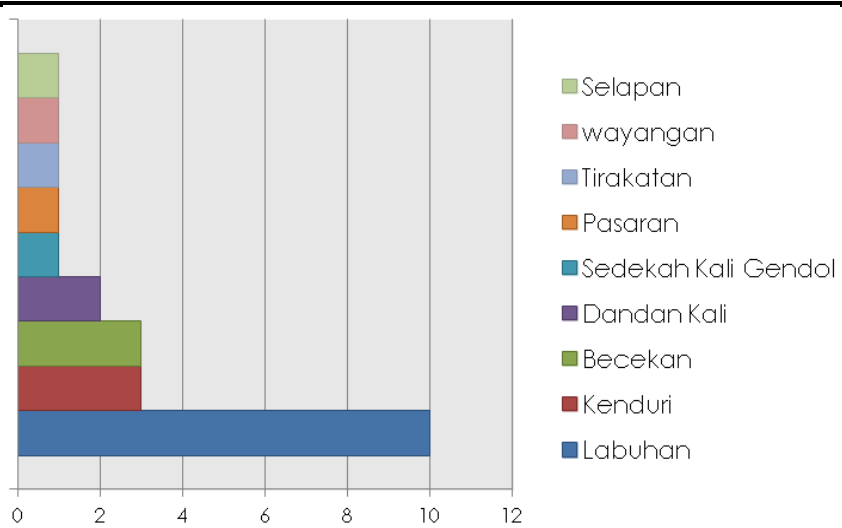

Sumber: Peneliti, 2014

\section{Grafik 2. Aktivitas Sosial Budaya Dalam Ingatan Responden}

Menurut hasil wawancara terhadap responden, diperoleh temuan bahwa hanya sekitar 16 responden dari 30 responden yang mampu menjelaskan tujuan dari tradisi budaya tersebut dilakukan. Sebagaiman dijelaskan sebelumnya bahwa hal ini disebabkan oleh adanya perubahan demografis desa Kepuhajo. Jenis tradisi, tujuan dan waktu penyelenggaraan tradisi Merapi yang dikenal oleh responden dapat diamati pada tabel 1.

Tabel 1. Jenis upacara budaya Merapi yang dikenal oleh responden Kepuharjo

\begin{tabular}{|c|c|c|c|}
\hline NO & Jenis Tradisi & Tujuan Tradisi & Penyelenggaraan \\
\hline 1 & Labuhan Gunung Merapi & $\begin{array}{l}\text { Memohon keselamatan dari penunggu Merapi } \\
\text { Sebagai ungkapan rasa syukur atas berkat yang diberikan } \\
\text { oleh gunungapi Merapi }\end{array}$ & 1 Suro \\
\hline 2 & Kenduri & Membersihkan dusun atau desa & - \\
\hline 3 & Becekan & $\begin{array}{l}\text { Meminta hujan, } \\
\text { Memohon kemakmuran dan keselamatan bagi warga } \\
\text { merapi }\end{array}$ & $\begin{array}{l}\text { Musim kemarau,musim ke-4 } \\
\text { Jumat Kliwon }\end{array}$ \\
\hline 4 & Dandan Kali & $\begin{array}{l}\text { Meminta berkah hujan } \\
\text { Memohon keselamatan }\end{array}$ & $\begin{array}{l}\text { Mongso papat setiap Jumat } \\
\text { Kliwon }\end{array}$ \\
\hline 5 & Sedekah Kali Gendol & $\begin{array}{l}\text { Memohon kepada penunggu gunungapi Merapi atau roh } \\
\text { halus agar air sungai cukup jumlahnya untuk memenuhi } \\
\text { konsumsi air minum bagi warga setempat }\end{array}$ & - \\
\hline 6 & Pasaran & & 35 hari sekali \\
\hline 7 & Tirakatan & Memohon keselamatan bagi keluarga & Malam 1 Muharam \\
\hline 8 & Wayangan & Mensyukuri keberadaan Merapi & \\
\hline 9 & Selapan & $\begin{array}{l}\text { Mendoakan arwah leluhur dan kerabat yang sudah } \\
\text { meninggal dalam bentuk peringatan }\end{array}$ & $\begin{array}{l}\text { Jumat Kliwon,legi, pahing, pon, } \\
\text { wage }\end{array}$ \\
\hline 10 & Sayur lodeh & Menolak bala/sial/kutuk. & \\
\hline
\end{tabular}

Sumber: Peneliti, 2014 
Penelitian menggunakan dua jenis variabel sebagai alat untuk mengidentifikasi tingkat pemahaman warga Merapi terhadap cerita maupun mitos yang telah berkembang secara turun temurun khususnya dalam kaitannya dengan pengetahuan akan mitigasi bencana erupsi melalui 30 responden. Kedua jenis variabel tersebut adalah tingkat pemahaman responden terhadap isi cerita rakyat, mitos dan aturan tradisional setempat serta makna ataupun pesan moral dan tujuannya bagi keberlangsungan permukiman Merapi. Dalam konteks kearifan lokal berbentuk oral di kawasan Merapi, dapat diperoleh informasi mengenai jenis-jenis cerita rakyat dan mitos yang selama ini cukup dikenal oleh para responden. Berdasarkan hasil wawancara dengan penduduk setempat, hanya $30 \%$ dari 30 responden yang memiliki wawasan yang memiliki penguasaan yang cukup baik terhadap cerita rakyat dan mitos yang telah lama berkembang di Merapi, termasuk pada aturan tradisional setempat. Profil penghuni permukiman di zona berbahaya sesunguhnya telah mengalami pergeseran, namun diperoleh 2 (dua) temuan penting yang perlu dikaji secara lebih mendalam. Kedua temuan penting tersebut dapat dijelaskan sebagai berikut:

1. Pengetahuan lokal terhadap cerita rakyat, mitos dan aturan tradisional membangun sebagian besar dikuasai oleh responden yang berusia antara 41 tahun hingga 50 tahun sedangkan responden yang berusia lebih lanjut (lebih dari 51 tahun) tidak memperlihatkan adanya pemahaman yang cukup mengenai kearifan lokal Merapi. Responden yang berusia lebih dari 51 tahun tersebut rata-rata adalah warga yang telah menghuni zona berbahaya lebih dari 30 tahun.

2. Hanya 7 responden dari 30 responden yang secara utuh menguasai jenis mitos dan memahami pesan moral, maksud dan tujuan di balik cerita rakyat, mitos dan aturan tradisional tersebut dalam kaitannya dengan pengetahuan mitigasi bencana. Hal ini dapat disebabkan oleh latar belakang responden yang rata-rata berasal dari luar wilayah Kepuharjo dan Yogyakarta.

Berdasarkan hasil wawancara dengan para responden, diperoleh jenis kearifan lokal yang melekat di benak responden dan dapat diamati pada tabel 2.

Tabel 2. Jenis kearifan lokal Merapi menurut pemahaman responden Kepuharjo

\begin{tabular}{|c|c|c|c|}
\hline NO & Kearifan lokal & Keterangan & Pesan Moral \\
\hline 1 & Cerita Rakyat & $\begin{array}{l}\text { a) Cerita wayang bahwa Merapi bersahabat } \\
\text { dengan warga setempat } \\
\text { b) Erupsi Merapi memiliki maksud tertentu. }\end{array}$ & $\begin{array}{l}\text { Warga tetap hidup selaras dengan alam } \\
\text { dalam damai dan menjaga kelestarian } \\
\text { gunung. }\end{array}$ \\
\hline 2 & Mitos & $\begin{array}{l}\text { a) Mitos hubungan antara Nyi Roro Kidul dengan } \\
\text { Kyai Sapu Jagad,dan adanya jalan lurus yang dilalui } \\
\text { oleh Nyi Roro Kidul dengan menggunakan kereta } \\
\text { kencana. } \\
\text { b) Hubungan antara penguasa Merapi dengan } \\
\text { penguasa Pantai Selatan } \\
\text { c) Juru kunci Merapi sebagai penghubung antara } \\
\text { Sultan dengan penunggu Merapi. } \\
\text { d) Merapi meletus karena penunggu Merapi ingin } \\
\text { melakukan pembersihan terhadap wilayahnya. }\end{array}$ & $\begin{array}{l}\text { a. Mengingatkan warga Merapi bahwa } \\
\text { gunungapi Merapi senantiasa aktif } \\
\text { sehingga potensi ancaman yang } \\
\text { mungkin saja terjadi harus diantisipasi } \\
\text { oleh warga. } \\
\text { b. Menjaga kelestarian lingkungan } \\
\text { Merapi termasuk elemen alamiah } \\
\text { sungai dan hutan dari pengrusakan } \\
\text { dan pencemaran. }\end{array}$ \\
\hline 3 & $\begin{array}{l}\text { Aturan } \\
\text { Tradisional }\end{array}$ & $\begin{array}{l}\text { a) Pintu utama rumah menghadap ke Selatan dan } \\
\text { harus menghadap ke jalan } \\
\text { b) Hari baik untuk membangun sesuai kalendar } \\
\text { Jawa. } \\
\text { c) Melakukan ritual Slametan di Pedukuhan agar } \\
\text { yang bekerja di rumah dalam kondisi baik yang } \\
\text { ditandai dengan peletakan batu pertama. } \\
\text { d) Menggunakan janur kuning sebelum } \\
\text { membangun; sebelum memasang atap harus } \\
\text { menggantung baju; menanam tebu hitam, pohon } \\
\text { pisang raja,daun dadap di tengah bangunan sebelum } \\
\text { membangun. } \\
\text { e) Membangun harus menjauh dari bantaran kali } \\
\text { Gendol } \\
\text { f) Larangan tidak boleh mencuci dari air gunung } \\
\text { karena jika mencuci dengan air itu maka air sungai } \\
\text { tidak akan mengalir. }\end{array}$ & $\begin{array}{l}\text { Menghormati gunungapi Merapi sebagai } \\
\text { yang memberikan kehidupan dan berkah } \\
\text { bagi warga sehingga warga diingatkan } \\
\text { bahwa dalam membangun hunian tidak } \\
\text { diperbolehkan menyakiti tubuh gunung } \\
\text { atau tidak memperhatikan lingkungan } \\
\text { Merapi. }\end{array}$ \\
\hline
\end{tabular}

Sumber: Peneliti, 2014 
Mengacu dari relasi antar sistem yag dikemukakan oleh Rapoport (1977), hubungan antara bentuk kearifan lokal oral, makna, pengetahuan mitigasi bencana, tradisi budaya dan tata ruang arsitektural dapat ditegaskan kembali sesuai dengan skema berikut:

Pola hubungan pada skema 3 digunakan sebagai dasar menganalisis kaitan antara pengetahuan lokal dengan tata ruang wilayah desa Kepuharjo melalui peta-peta analisis yang akan dibahas selanjutnya.

\section{Fungsi Lahan dan Fasilitas Publik}

Bentuk ruang kawasan Desa Kepuharjo memiliki pola organik tidak terencana yang bercampur dengan sebagian pola grid sebagai akibat dibangunnya hunian sementara oleh Pemerintah Daerah paska erupsi tahun 2010. Berdasarkan peta analisis fungsi lahan dan fasilitas publik pada gambar 2 dapat diamati bagaimana nilai-nilai budaya dan pengetahuan mitigasi bencana melalui bentuk cerita rakyat, mitos dan aturan tradisional diterapkan ke pengaturan fungsi lahan dan fasilitas publik kawasan Desa Kepuharjo.

\section{Sistem Jaringan Transportasi}

Sebagian besar kondisi jalan Desa Kepuharjo berada pada tahap perbaikan akibat tingginya intesitas aktivitas armada pembawa material pasir dari sungai Gendol ke lokasi penampungan. Sistem jalan yang terbangun umumnya belum sepenuhnya menjangkau seluruh permukiman khususnya di bagian Utara desa sehingga akan mempengaruhi proses evakuasi bencana di masa depan. Namun di satu sisi, hal tersebut dilakukan oleh Pemerintah Daerah untuk menghindari berkembangnya kegiatan warga ke zona berbahaya dengan melakukan pembatasan akses ke zona tersebut yang mengarah ke puncak Merapi.

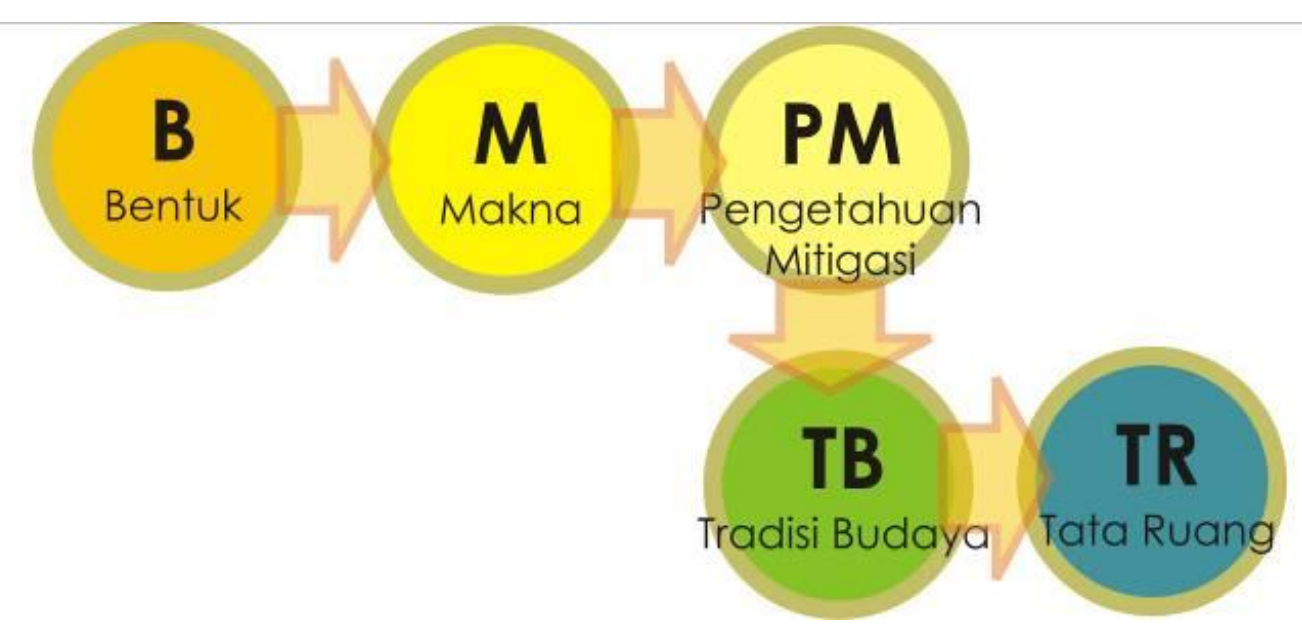

Sumber: Peneliti, 2014

Skema 3. Hubungan Antara Bentuk Kearifan Lokal Berbentuk Oral Ke Bentuk Konkrit 


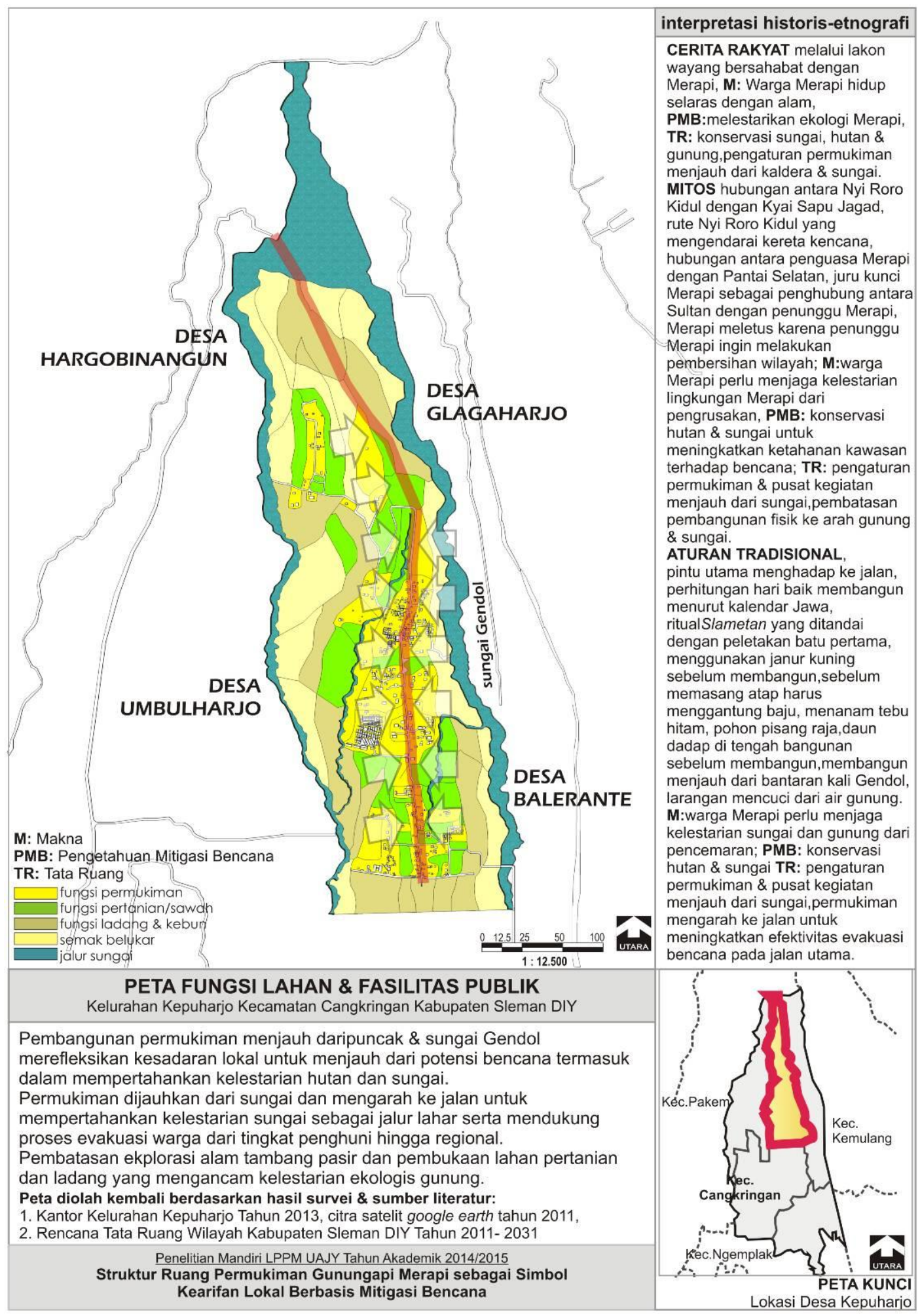

Gambar 2. Peta analisis fungsi lahan dan fasilitas publik Desa Kepuharjo Cangkringan 


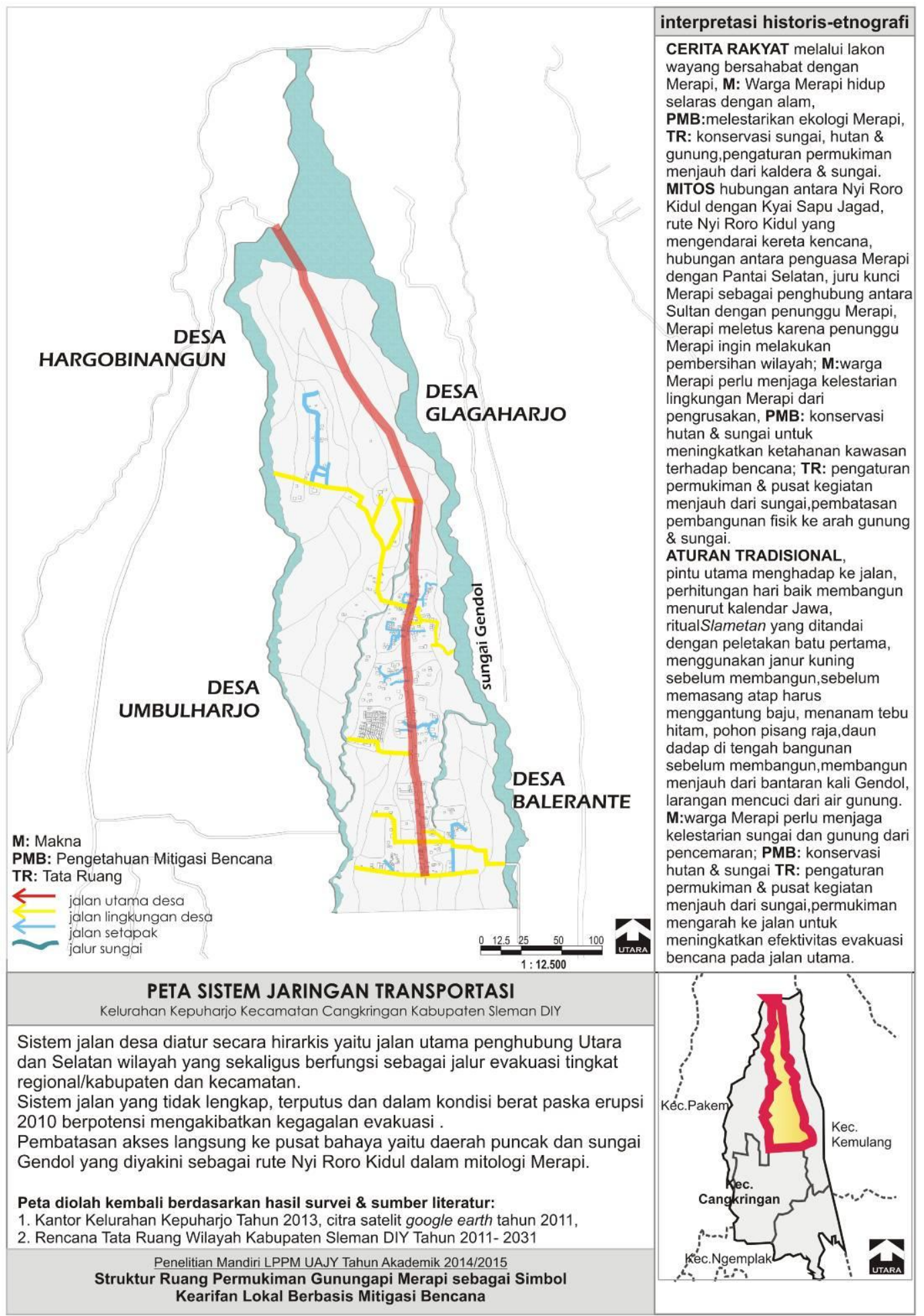

Sumber: Peneliti, 2014

Gambar 3. Peta sistem jaringan transportasi publik Desa Kepuharjo Cangkringan 
Dalam kaitannya dengan kebutuhan masa kini akan ruang-ruang ekonomi yang baru, terjadi sejumlah perubahan terhadap pola hidup dan tata ruang kawasan setempat. Beberapa bentuk adaptasi warga Kepuharjo terhadap tata ruang fisik setempat untuk menanggapai kebutuhan ekonomi, adalah:

1. Pengaturan permukiman yang mendekati area jalan, menjauh dari sumber-sumber bahaya yaitu puncak gunung/kaldera gunungapi Merapi dan sungai Gendol.

2. Pembatasan pembangunan fisik ke arah gunung dengan mempertahankan keberadaaan dan fungsi hutan semak belukar.

3. Pembukaan area sawah dan ladang yang diatur agar tidak mengganggu keseimbangan ekosistem Merapi yang penting bagi keberlangsungan hidup warga.

4. Pembangunan sistem jalan yang terhubung secara langsung dan jelas yang ditujukan untuk mendukung proses evakuasi bencana di masa yang akan datang. Sistem jalan dilengkapi oleh papan tanda rute evakuasi meskipun belum seluruhnya diterapkan termasuk sistem penerangan desa yang memadai.

5. Pembatasan akses ke zona berbahaya mendekati puncak Merapi.

6. Orientasi hadap bangunan diwajibkan ke arah jalan dan tidak mengarah ke puncak Merapi. Hal ini secara tidak langsung memberi keuntungan bagi warga setempat untuk dapat melakukan evakuasi awal pada skala hunian dan regional.

7. Pembangunan permukiman berupa hunian sementara/huntara, desa wisata dan fasilitas pendukung kepariwisataan di wilayah Desa Kepuharjo merefleksikan adanya programprogram pembangunan berbasis mitigasi bencana dan pariwisata. Program-program tersebut harus didukung oleh sistem evakuasi dan manajemen bencana yang sistemik dan terkoordinasi secara integratif dan komprehensif antar aparatur daerah, regional, pelaku bisnis serta warga setempat. Fasilitas kepariwisataan yang telah terbangun seperti hotel dan fasilitas golf Merapi yang menyerap tenaga kerja setempat, museum dan gardu pandang termasuk fasilitas komersial harus memperoleh pengawasan dalam proses pengembangan dan pembangunannya agar tidak mengancam keseimbangan ekologis Merapi. Sistem utlitas bangunan atau fasilitas tersebut, baik yang berkaitan dengan pengadaan air bersih dan pengelolaan limbah sangat potensial merusak struktur alami geologi gunung sehingga perlu pula dipertimbangkan secara seksama.

\section{Kesimpulan}

Berdasarkan hasil wawancara dengan para responden warga Kepuharjo, diinvetarisasi sejumlah kearifan lokal yang selama ini cukup dikenal oleh para responden, yaitu Labuhan Merapi, tradisi kenduri, becekan, dandan kali dan tradisi sedekah Kali Gendol. Pengetahuan mitigasi bencana di balik masing-masing tradisi dan kearifan lokal tersebut diterjemahkan ke dalam desain ruang dan tata ruang permukiman Desa Kepuharjo, yaitu dengan:

1. Mengatur fungsi lahan dan fasilitas publik agar menjauh dari daerah berbahaya, yaitu puncak Merapi dan sungai Gendol yang berperan sebagai jalur lahar.

2. Membatasi pembangunan fisik dan akses ke arah puncak gunung dan sungai Gendol yang berpotensi mengancam keselamatan jiwa warga pemukim.

3. Mempertahankan keasrian alam gunung dengan sejauh mungkin mempertahankan keberadaan hutan semak belukar sebagai hutan lindung yang memproteksi kawasan permukiman di bawahnya.

4. Membangun sistem jalan yang didukung oleh infrastruktur evakuasi berupa papan rute evakuasi khususnya pada jalan-jalan utama kawasan.

5. Memperbaiki jalan utama dari kerusakan dengan membatasi aktivitas armada penambang pasir yang relatif rutin berlangsung di daerah desa. 


\begin{tabular}{|c|c|}
\hline \multirow[b]{2}{*}{$\begin{array}{l}\text { s jalur evakuasi utama } \\
\text { In petunjuk arah \& berkualitas aspal } \\
\text { kses dan melarang pembangunan fisik ke } \\
\text { pada implementasinya masih ditemukan sejumlah } \\
\text { nembangun pada zona berbahaya tersebut, }\end{array}$} & interpretasi historis-etnografi \\
\hline & $\begin{array}{l}\text { CERITA RAKYAT melalui lakon } \\
\text { wayang bersahabat dengan } \\
\text { Merapi, M: Warga Merapi hidup } \\
\text { selaras dengan alam, } \\
\text { PMB:melestarikan ekologi Merapi, } \\
\text { TR: konservasi sungai, hutan \& } \\
\text { gunung,pengaturan permukiman } \\
\text { menjauh dari kaldera \& sungai. } \\
\text { MITOS hubungan antara Nyi Roro } \\
\text { Kidul dengan Kyai Sapu Jagad, } \\
\text { rute Nyi Roro Kidul yang } \\
\text { mengendarai kereta kencana, } \\
\text { hubungan antara penguasa Merapi } \\
\text { dengan Pantai Selatan, juru kunci } \\
\text { Merapi sebagai penghubung antara } \\
\text { Sultan dengan penunggu Merapi, } \\
\text { Merapi meletus karena penunggu } \\
\text { Merapi ingin melakukan } \\
\text { pembersihan wilayah; M:warga } \\
\text { Merapi perlu menjaga kelestarian } \\
\text { lingkungan Merapi dari } \\
\text { pengrusakan, PMB: konservasi } \\
\text { hutan \& sungai untuk } \\
\text { meningkatkan ketahanan kawasan } \\
\text { terhadap bencana; TR: pengaturan } \\
\text { permukiman \& pusat kegiatan } \\
\text { menjauh dari sungai,pembatasan } \\
\text { pembangunan fisik ke arah gunung } \\
\text { \& sungai. } \\
\text { ATURAN TRADISIONAL, } \\
\text { pintu utama menghadap ke jalan, } \\
\text { perhitungan hari baik membangun } \\
\text { menurut kalendar Jawa, } \\
\text { ritualSlametan yang ditandai } \\
\text { dengan peletakan batu pertama, } \\
\text { menggunakan janur kuning } \\
\text { sebelum membangun,sebelum } \\
\text { memasang atap harus } \\
\text { menggantung baju, menanam tebu } \\
\text { hitam, pohon pisang raja,daun } \\
\text { dadap di tengah bangunan } \\
\text { sebelum membangun,membangun } \\
\text { menjauh dari bantaran kali Gendol, } \\
\text { larangan mencuci dari air gunung. } \\
\text { M:warga Merapi perlu menjaga } \\
\text { kelestarian sungai dan gunung dari } \\
\text { pencemaran; PMB: konservasi } \\
\text { hutan \& sungai TR: pengaturan } \\
\text { permukiman \& pusat kegiatan } \\
\text { menjauh dari sungai,permukiman } \\
\text { mengarah ke jalan untuk } \\
\text { meningkatkan efektivitas evakuasi } \\
\text { bencana pada jalan utama. }\end{array}$ \\
\hline \multicolumn{2}{|l|}{$\begin{array}{l}\text { ADAPTASI WARGA TERHADAP POTENSI BENCANA } \\
\text { Kelurahan Kepuharjo Kecamatan Cangkringan Kabupaten Sleman DIY }\end{array}$} \\
\hline $\begin{array}{l}\text { Paska erupsi Merapi pada bulan November } 2010 \text { silam, sejumlah langkah mitigasi } \\
\text { bencana dipersiapkan oleh Pemerintah dan warga untuk menghadapi ancaman bencana } \\
\text { di masa yang akan datang. Pembangunan hunian sementara yang didanai oleh JICA dan } \\
\text { Kementerian PU/KOMPAK ke arah Selatan di luar zona berbahaya, diterapkan. } \\
\text { Kandang ternak sapi secara komunal dikelola oleh warga dengan membangun kandang } \\
\text { sapi di luar zona berbahaya wilayah Kepuharjo (radius } 5 \text { kilometer dari puncak). } \\
\text { Memperjelas jalur evakuasi utama desa Kepuharjo dengan papan tata tanda evakuasi dan } \\
\text { perbaikan kualitas jalan untuk membangun hubungan jalan antar wilayah. } \\
\text { Membatasi akses dan pembangunan ke arah gunung dan Kali Gendol, hal ini selaras } \\
\text { dengan aturan tradisional setempat. } \\
\text { Peta diolah kembali berdasarkan hasil survei \& sumber literatur: } \\
\text { 1. Kantor Kelurahan Kepuharjo Tahun } 2013 \text {, citra satelit google earth tahun 2011, } \\
\text { 2. Rencana Tata Ruang Wilayah Kabupaten Sleman DIY Tahun 2011- } 2031\end{array}$ & ulang \\
\hline $\begin{array}{c}\text { Penelitian Mandiri LPPM UAJY Tahun Akademik 2014/2015 } \\
\text { Struktur Ruang Permukiman Gunungapi Merapi sebagai Simbol } \\
\text { Kearifan Lokal Berbasis Mitigasi Bencana }\end{array}$ & \\
\hline
\end{tabular}

Sumber: Peneliti, 2014

Gambar 4. Adaptasi Warga Kepuharjo Terhadap Kebutuhan Masa Kini Dan Konteks Kebencanaan Pada Tata Ruang Permukiman Desa Kepuharjo 
Kebutuhan akan peningkatan kesejahteraan hidup bagi warga setempat diperlihatkan dengan dibukanya akses terhadap program-program pembangunan modern khususnya yang berhubungan dengan kepariwisataan. Fasilitas utama dan pendukung pariwisata Merapi yang berkembang di kawasan Desa Kepuharjo antara lain berupa tempat penginapan/hotel dan fasilitas golf Merapi, bangunan komersial dalam skala mikro, museum dan bisnis rekreasional lainnya. Pembangunan barak-barak pengungsian dan hunian sementara pada radius sekitar 7 kilometer dari puncak Merapi ditujukan untuk meningkatkan keselamatan warga dari potensi bahaya sedangkan ternak lokal yang umumnya berupa sapi perah dan sapi potong dikumpulkan pada satu fasilitas bersama yang dilokasikan lebih jauh dari hunian/permukiman warga. Pembangunan sektor pariwisata dan industri yang berkembang di kawasan Desa Kepuharjo dan permukiman Merapi lainnya perlu diawasi secara seksama dengan mengendalikan rencana tata ruang wilayah setempat sehingga dampak bencana erupsi di masa yang akan datang dapat direduksi.

Belajar dari peristiwa erupsi Merapi pada November 2010, pengetahuan lokal akan mitigasi bencana perlu dilestarikan dengan mengangkat kembali pengetahuan masa lampau, baik yang terkandung dalam mitos, cerita rakyat maupun aturan tradisional sebagai media efektif untuk mentransfer pengetahuan mitigasi bencana. Dengan demikian, ketahanan komunitas terhadap dampak erupsi semakin meningkat. Hal tersebut dapat dilakukan dengan mengembangkan riset-riset yang berfokus pada upaya untuk mengungkap mitos-mitos, cerita rakyat dan aturan tradisional dari masa lalu serta kaitannya dengan pengetahuan mitigasi bencana dan implementasinya ke dalam rencana tata ruang daerah rawan bencana. Pada konteks kawasan Desa Kepuharjo, pengaruh langsung kearifan lokal khususnya yang berbasis mitigasi bencana tidak terlalu banyak ditemukan kecuali pada prinsip-prinsip pengaturan fungsi lahan dan sistem jalan sebagai jalur aman bagi warga pemukim. Dengan demikian, perlu diteliti lebih lanjut di masa yang akan datang apakah pengaturan tersebut lebih dilandaskan oleh pengetahuan modern, kebijakan Pemerintah atau berdasarkan inisiatif warga yang didorong oleh pemahaman lokal akan mitigasi bencana sebagaimana yang diwariskan melalui kearifan lokal setempat.

\section{Daftar Pustaka}

Anon., 2011. Islam dan Kearifan Lokal dalam Penanggulangan Bencana di Jawa. Jurnal Penanggulangan Bencana, II(1), hal. 1-10.

Casuarina, Y., 2003. Cerita Rakyat Gunung Merapi di Kelurahan Hargobinagun Kecamatan Pakem Kabupaten Sleman Daerah Istimewa Yogyakarta. Surakarta: Fakultas Sastra dan Seni Rupa Universitas Sebelas Maret.

Desa Kepuharjo, P., 2013. Rencana Pembangunan Jangka Menengah Desa Kepuharjo Kecamatan Cangkringan Kabupaten Sleman, Kabupaten Sleman, Daerah Istimewa Yogyakarta: Desa Kepuharjo Kecamatan Cangkringan.

Ernawi, I., 2010. Harmonisasi Kearifan Lokal Dalam Regulasi Penataan Ruang. s.l., Seminar Nasional "Urban Culture, Urban Future : Harmonisasi Penataan Ruang dan Budaya untuk Mengoptimalkan Potensi Kota, hal. 121.

Fatkhan, M., 2006. Kearifan Lingkungan Masyarakat Lereng Gunung Merapi. Jurnal Aplikasi llmu-Ilmu Agama, VII(2), pp. 107-121.

Groat, L. \& Wang, D., 2002. Architectural Research Methods. New York: John Wiley \& Sons, Inc.

Haryadi \& Setiawan, B., 2010. Arsitektur Lingkungan dan Perilaku:Pengantar ke Teori, Metodologi dan Aplikasi. Yogyakarta: Gadjah Mada University Press.

Indonesia, K. B. B., 2012. [Online] Available at: www.kbbi.com [Diakses 2013].

Kabupaten Sleman, P., 2013. Peta Kawasan Rencana Bencana Kabupaten Sleman Tahun 2011-2031, Sleman: Bappeda Kabupaten Sleman.

Maarif, S., Pramono, R. \& Kinseng, R., 2012. Kontestasi Pengetahuan dan Pemaknaan Tentang Ancaman Bencana Alam Studi Kasus Ancaman Bencana Gunung Merapi. Jurnal Penanggulangan Bencana, III(1), pp. 1-13.

Permana, R. \& Nasution, I., 2011. Kearifan Lokal tentang Mitigasi Bencana pada Masyarakat Baduy. Makara Sosial Humaniora, XV(1), pp. 67-76.

Rapoport, A., 1977. Human Aspects of Urban Form Towards A Man Environment Approach to Urban Forms and Design. London: Pergamon Press.

Sardjono, A., Budihardjo, E., Pangarsa, G. \& Prianto, E., 2013. Arsitektur dalam Perubahan Kebudayaan. 
Schultz, C. N., 1980. Genius Loci: Towards A Phenomenology of Architecture. New York: Rizzoli.

Setyowati, E., 2007. Karakteristik Ruang Kawasan Dalam Beteng Kraton Yogyakarta. Forum Teknik, Volume 30, No. 3, hal.197-272.

Sleman, P. K., 2013. Rencana Tata Ruang Kabupaten Sleman Tahun 2011-2031. Kabupaten Sleman: Bappeda Sleman, Daerah Istimewa Yogyakarta.

Wahyunto \& Wasito, t.thn. Lintasan Sejarah Erupsi Merapi. Pengembangan Pertanian Berbasis Inovasi di Wilayah Bencana Erupsi Gunung Merapi. Bogor, hal. 13-37.

Wiryomartono, A., 1995. Seni Bangunan dan Seni Binakota di Indonesia. Jakarta: PT. Gramedia Pustaka Utama. 